\title{
How Different Kinds of Innovation Affect Trade Performance of Enterprises in China?
}

\author{
Ying $\mathrm{Ma}^{1} \quad$ Abdul Rauf ${ }^{2 *}$ \\ 1.Centre for Economic Development Research (CEDR), Economics and Management School of Wuhan \\ University, Luojia Hill, Wuhan, Hubei 430072, P.R. China \\ 2.Economics and Management School of Wuhan University, Luojia Hill, Wuhan, Hubei 430072, P.R. China
}

The authors greatly acknowledge financial support from the Ministry of Education, P.R., China for the major research project "A Study on the Transformation of China's Outward Pattern of Economic Development (13JJD790021)".

\section{Abstract}

The paper aims to empirically investigate the impact of the different kinds of technological innovation on export performance of Chinese manufacturing industries. To do this, we distinguish between different dimensions of innovation activities including R\&D intensity, innovation capability, invention intensity, skill intensity, foreign technology and new product development, and examine their distinct impact on industrial export. The fixed-effect and instrumental variable (IV) regression methods have been applied on a panel dataset of China's two-digit manufacturing industries over the 1998-2013 period. The results indicate that R\&D intensity and innovation capability are significant determinants of export performance in China while the effect that innovation capability have made on export is greater than R\&D intensity. In addition, invention intensity, skill intensity and foreign technology have broadly accelerated the export performance of China's manufacturing industries. However, skill intensity and foreign technology have the relatively stronger effect on export among different kinds of innovation indicators. Furthermore, Chinese exports have greatly benefitted from the activities which are linked to the new product development. Our result reveal that China's inclusion into WTO in 2002 has been a stimulating factor for country's trade liberalisation process. These results are robust to several tests and sensitivity checks, as well as alternative measures on various channels of technological innovation. The evidence has significant policy lessons for China and other emerging countries.

Keywords: R\&D, Innovation output, Invention intensity, New product development, Foreign Technology transfer, Export performance

DOI: $10.7176 / \mathrm{JESD} / 10-10-07$

Publication date:May $31^{\text {st }} 2019$

\section{Introduction}

Exports is considered as a vital part of the most debated development plans in emerging economies. The wave of globalisation since 1980s has appeared to reveal the fact that high technology manufactured products constitute the fastest increasing share of world trade (Lall, 2003). The underlying theoretical framework on this perspective is the remarkable success of Asian economies (First Japan, then NIEs, after that ASEAN-4 and recently China) which, during the process of development, successfully shifted production processes from low-tech and primary industries to manufacturing industries and their trade pattern transformed to the export of more technical and quality products. The success story of these countries has motivated many researchers to conduct studies for examining the drivers of their growth trajectories and for deriving the useful insights from this remarkable experience. However, much less attention has been provided to investigate the role of innovation in astounding export performance of these developing countries. Especially, how different kinds of innovation affect export structure in emerging countries is yet a rarely explored area of research. This paper aims to examine the extent to which different kinds of innovation have contributed to improve the performance of manufactured export in China.

Given ongoing state of the economy and the endeavour to transform the outward pattern of economic development by integrating into technological upgrading efforts, mainly by focusing on the improvement of the different kinds of innovation expertise, China provides an important case study. In fact, China has seen several decades of spectacular growth. Since reforms and opening-up in 1978, numbers from the National Bureau of Statistics of China (NBSC) reveal that its real GDP grew at an annual rate of nearly 10 percent and the share of exports in GDP raised from almost nothing in 1970s to notably 37 percent in 2006. More impressive is the development of its high technology share of manufactured exports which grew at an annual rate of 21.3 percent over 1992-2015 period (NBSC). This magnificent experience has transformed its position from an isolated country to the status of a largest economy only second to USA and world's leading exporting country. More impressive is the transformation of its exports structure from agriculture and apparel to electronics and complex machinery (Amiti \& Freund, 2010) and the endeavour to enhance indigenous innovative capacity and to create favourable spillovers from diffusion of international technology (Brandt \& Thun, 2010; Liu and Buck, 2007; Tang \& Hussler, 2011). However, after decades of this impressive economic performance, Chinese economy is settling itself from 
high to moderate growth regime. This phenomenon has already increased the importance of innovation activities in the country. In addition, upgrading to a more technical and productive industrial structure, which may provide a cost advantage and returns to scale benefits, and expanding into new products by relying on technological innovation is crucial for China at this stage.

Researchers and policy makers, in China and around the world, highlight the potential contribution of technological innovation and creating broad based spillovers from foreign technology to restore the pace of development and to ensure sustainable growth in the future. Theoretically, this phenomenon is related to the importance of innovation and invention to increase the productivity and efficiency of production processes which, in turn, encourage returns to scale, lower average costs and provide an industry competitive advantage in world market based on lower cost and higher quality products (Zhu \& Fu, 2013). Further useful insights about innovationexport interplay provide that China need to shift its industrial structure from low-tech and skill-intensive industries to that is dominated by technology-intensive industries.

A substantial part of theoretical and empirical research literature on the pattern of outward orientation of a country is conclusive that shifting the structure of exports from less productive, primary and low-tech agriculture sector to more productive manufacturing sector is necessary in order to lift a country from low-income group and take it to join the club of middle-income countries (Hausmann et al., 2007; Sheridan, 2014), while the role of different kinds of technological innovation is emphasized in the catching-up process for developing a competitive outward pattern of economic development (Hidalgo, 2007; Hidalgo \& Hausmann, 2009). As export competitiveness is measured by the intensity of technology used in its manufacture, it is of crucial importance to examine how different kinds of technological innovation are linked to accelerating the international competitiveness of developing countries.

Standard classical and neo-classical models rely on the assumptions of constant returns to scale and perfect competition, thereby explain innovation a little. New growth theory finds the opportunity to incorporate returns to scale and the knowledge capital to explain the process of innovation as an endogenous factor of a production process (Grossman \& Helpman, 1994; Romer, 1990, 1994). Krugman (1979) explains that countries are differentiated by their level of technology and whosoever is ahead specialize in technology intensive products. Innovation make production process to exhibit higher productivity and increasing return to scale that, in turn, give first mover advantage. The variation of countries in real per capita income can be explained by varieties of products and quality of product (Funk \& Ruhwedel, 2001; Grossman \& Helpman, 1991; Hummels \& Klenow, 2004). Export upgrading in terms of variety of higher quality goods allow high income countries to increase their export volume without lowering price (Funk \& Ruhwedel, 2001; Hummels \& Klenow, 2004). The process of innovation involves enhancing the potential to produce new and a variety of products in such a way that, at the given input prices, these products are lower in cost value and higher in quality than the already available product chain. Ample theoretical and empirical research on the channels of technological upgrading consider the role of domestic innovation activities, the rate of the diffusion of international technology and the quality of institutions as major determinant of technological innovation in developing countries (Brandt \& Thun, 2010; Fu \& Gong, 2010; Furman et al., 2002; Liu \& Buck, 2007), while a threshold level of absorptive capacity is crucial to take the required spillovers from imports and FDI (Fu, 2008; Liu \& Buck, 2007). As the technological content embodied in exporting commodities define the level of a country's export competitiveness, the factors which drive technological innovation are fundamental determinants of the level and extent of export upgrading.

Existing literature mainly focus on GDP per capita, human capital and Government policies to determine the level of exports sophistication (Hausman et al., 2007; Rodrik, 2006; Schot, 2008; Wang \& Wei, 2010) arguing that what matters for efficient functioning of a country's development process is the quality of products it exports, while the monetary value of exports flow is a less impressive factor in this concern. Furthermore, new trade theories which are associated with the endogenous growth theory emphasize the role of invention and innovation and the subsequent importance of new product development suggest that expansion of a country's productivity frontier in terms of new products contribute to the export sophistication which, in turn, lead to sustained growth in the long run (Amiti \& Freund, 2010; Hausmann et al., 2007 Hummels \& Klenow, 2005). But these studies undermine the role of knowledge capital in determining the level of export upgrading in an industry. In their recent study on a panel of low, middle- and high-income countries over 1992-2006 period, Zhu and Fu (2013) emphasize the role of knowledge capital as major driver of export upgrading examining that knowledge generating factors as measured by education, R\&D intensity, FDI, imports and institutional quality are crucial determinants of export upgrading in developing countries.

The paper investigates the role of different kinds of technological innovation including R\&D intensity, patents, invention intensity, human capital and new product development. Existing literature normally focus on the importance of these channels to determine the level and structure of technological upgrading in developed vs developing countries (Fu \& Gong, 2010; Liu \& Buck, 2007; Sun \& Du, 2010) while much less attention has been paid to investigate their impact on export performance in emerging countries. This paper intends to investigate the impact of innovation on export by distinguishing between different kinds of technological innovation using a 
unique panel dataset of Chinese manufacturing industries. These industries constitute major part of innovative activates and contribute to a broader perspective of industrial activities than Chinese high-tech industries. Further, we take into account the recommendations of self-selection hypothesis and learning by exporting that there may exist reverse causality in the relationship among innovation and export which may lead to significant endogeneity bias and renders traditional fixed and random effect estimations inconsistent. We deal with the problem of endogeneity by using Instrumental Variable (IV) methods. For robustness, we use separate specifications of the regression equation by excluding and including foreign technology variable which show high correlation with other variables in the equation.

The paper addresses the above-mentioned debate by using unique industry-level data on China's manufacturing industries to investigate empirically the impact of different kinds of technological innovation on export performance in China over 1998-2013 period. We test the strength of our analysis by distinguishing between different measures on the different dimensions of technological innovation. Therefore, the novel contribution of this paper is evaluating the success of China's ongoing technology upgrading efforts, to become an innovationdriven country by $2020 \mathrm{~s}$, through shifting the focus to more technical industrial structure and the transformation of its outward pattern of economic development.

Empirical results of the paper show R\&D intensity, which has often been used as a measure of innovation input, and innovation capability are significant determinants of export performance in China while our findings show that the effect that innovation capability have made on export is greater than R\&D intensity. In addition, invention intensity, skill intensity and foreign technology have broadly accelerated the export performance of China's manufacturing industries. However, skill intensity and foreign technology have the relatively stronger effect on export among indicators on different kinds of innovation. Furthermore, Chinese exports have greatly benefitted from the activities which are linked to the new product development. Our result reveal that China's inclusion into WTO in 2002 has been a stimulating factor for country's trade liberalisation process.

The reminder of this paper is organised as follows. The next section discusses the analytical framework for this empirical study which includes variables, data and methodology. Section 3 presents the empirical results and discussions. In the last, section 4 conclude the analysis and provide policy implications.

\section{Methodology, Variables and Data}

Following the preceding discussion, export performance of an industry is considered as a function of various factors distinguishing between different kinds of an industry's innovative capability including: R\&D intensity, innovation capability, invention intensity, skill intensity, foreign technology, new product development and other. Our estimable equation takes the following form.

$$
\begin{aligned}
\text { EXPUP }_{i t}=\beta_{0} & +\beta_{1} R \& D_{-} \text {int }_{i t}+\beta_{2} \text { Patent_emp } \\
& +\beta_{4} \text { Skill_int }_{i t}+\beta_{5} \text { Invention_int }_{i t} \\
& +\beta_{9}(K / L)_{i t}+v_{i}+v_{t}+\varepsilon_{i t}
\end{aligned}
$$

Where subscript $\mathrm{i}$ denotes industry, $\mathrm{t}$ denotes time, $\mathrm{u}_{\mathrm{i}}$ represents industry specific fixed effect, $\mathrm{v}_{\mathrm{t}}$ denotes timespecific fixed effect and $\varepsilon_{i t}$ is random error term which is uncorrelated with any of the industry-specific or time specific effects and the independent variables. EXP is the dependent variable of export performance. R\&D_int represents R\&D intensity, Patent_emp denotes innovation capability, Invention int reads invention intensity, Skill_int represents the skill intensity of an industry, For-tech measures foreign technology, NPD denotes new product development, WTO measure the effect of China's inclusion into world trade and on its industrial export, $\mathrm{K} / \mathrm{L}$ show factor endowment and I represents institutional effectiveness. All variables appear in natural log form in regression models.

The paper is drawn on two-digits sub-sector level industries of China's manufacturing sector which are designated in compliance with the National Bureau of Statistics' industrial classification system. Data on comprehensive measures of the different kinds of technological innovation, over 1998-2013 period is taken from different database including UN Comtrade database, Ministry of Science and Technology (MST) of China and from various issues of China Statistical yearbook (CSY) as compiled by China National Bureau of Statistics.

\subsection{Dependent variable.}

The present study is concerned with the dynamics of factor intensity of a production process and the resulting pattern of trade at the enterprise-level. Thus, we rely on the value of manufactured exports per employee as our dependent variable of export performance. This measure is appropriate for analysing export performance of subsector level industries of a broader sector such as manufacturing. A notable complication arises while constructing this measure as China's industrial classification system is different than other commonly used industrial classification such as International Standard Industrial Classification (ISIC), hence industrial trade statistics are not reported for China's two-digit manufacturing industries in the designated data arrangements. Fortunately, Sheng Bin (2002) provides correspondence between System International Trade Classification (SITC) three digits 
level to China's Industrial Classification of the National Economy (ICNE) two digits sub-sector level industries. We follow this correspondence to convert SITC three-digit export statistics, which is collected from United nations Comtrade database, into ICNE two-digit industries and obtains export statistics for our dependent variable.

\subsection{Independent variables}

Independent variables used in the paper are summarised below. These variables are included to capture the effect of different kinds of technological innovation on export. In addition, these measures comprehensively ascertain distinct features of an industry's innovation structure and help increase our understanding of the relationship between technological innovation and export. Mainly we have captured the effect of the different kinds of innovation by distinguishing between the following six different variables: R\&D intensity, Patents, Invention intensity, Skill intensity, Foreign technology and New product development.

The knowledge about the input of an innovation process is important to evaluate the direct cost of innovation. Thus, an efficient selection of the level of innovation input may increase the likelihood of a well-directed innovation output. We include the variable of innovation input into our analysis to capture this phenomenon. Innovation input is capture by the $R \& D$ intensity ( $R \& D$ int) variable which is measured by the ratio of the value of intramural R\&D expenditure to overall employees of an industry. Spending on research and development is crucial for enhancing science and technological development processes and the innovative activities in an industry.

Output of an innovation process is a significant determinant of a firm's innovation excellence. A substantially innovative firm produces more innovations than the ordinary and less-productive firms. We include the patents count variable (Patent_emp) to incorporate the effect of innovation output into our analysis. Patent_emp variable is measured by number of patent applications accepted per employee of domestic enterprises in an industry. Patents are output of innovation process and reflects the score of a firm's innovative capability. Higher the number of patents owned by a firm, higher the credibility of its innovative expertise and higher the possibility of exporting high-technology embedded export bundles (Rodil et al., 2016; Zhu \& Fu, 2013).

Besides measuring the number of overall patents, we have also included the number of invention patents to specifically determine the effect of invention intensity on export performance of enterprises. This effect is captured by the invention intensity variable (Invention_int). The Invention_int variable is measured by number of invention patent application accepted of domestic enterprises in an industry. Patents are mainly recorded in three categories: invention, utility model and external design. However, invention patents reflect a firm's innovation intensity to a larger extent. This variable gives us two advantages: First, invention patents are more an interpretative of an industry's potential of producing new products unlike utility models which are related to the shape and structure of the product and external design patents which indicate designs about shape, colour or pattern of a product ( Fu, 2008); Second, invention patents describe the threshold level for comparing innovation expertise and help minimize the discrepancy among patents filed by domestic and foreign firms, as domestic firms may file application for utility model or external design patents, which are incomparable to foreign firm's invention patents (Sun \& Du, 2010).

Table 1. Description of variables

\begin{tabular}{|c|c|c|c|}
\hline Variables & Sub & Measurements & $\begin{array}{l}\text { Expected } \\
\text { Sign }\end{array}$ \\
\hline \multicolumn{4}{|l|}{ Dependent Variable } \\
\hline $\begin{array}{l}\text { Export performance } \\
\text { Independent }\end{array}$ & EXP & Value of manufactured exports per employee in an industry & \\
\hline \multicolumn{4}{|l|}{ Variables } \\
\hline New $\quad$ Product & & Lag of the ratio of expenditures on the development of new & \\
\hline \multicolumn{4}{|c|}{ 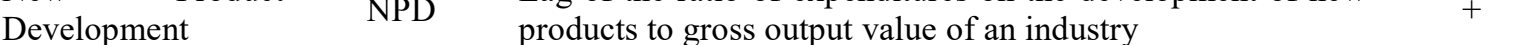 } \\
\hline \multicolumn{4}{|c|}{ Ratio of R\&D expenditure to total employees in an industry } \\
\hline \multirow{2}{*}{\multicolumn{4}{|c|}{$\begin{array}{l}\text { Number of overall patent applications accepted per employee } \\
\text { in an industry }\end{array}$}} \\
\hline & & in an industry & + \\
\hline Invention Intensity & $\begin{array}{l}\text { Invention } \\
\text { int }\end{array}$ & $\begin{array}{l}\text { Number of invention patent applications accepted per } \\
\text { employee in an industry }\end{array}$ & + \\
\hline \multirow{2}{*}{$\begin{array}{l}\text { Foreign Technology } \\
\text { Skill Intensity }\end{array}$} & For_tech & Value of foreign fixed assets in an industry & + \\
\hline & Skill_int. & $\begin{array}{l}\text { Number of scientists and engineers as a ratio of overall } \\
\text { employees in an industry }\end{array}$ & + \\
\hline Factor endowment & $\mathrm{K} / \mathrm{L}$ & $\begin{array}{l}\text { Ratio of the value of investment in fixed assets to overall } \\
\text { employment in an industry }\end{array}$ & + \\
\hline WTO & WTO & $\begin{array}{l}\text { A dummy variable measuring the effect of China's inclusion } \\
\text { into WTO, } 1 \text { for } 2001-04\end{array}$ & + \\
\hline Institutions & I & Number of private enterprises in an industry & + \\
\hline
\end{tabular}

Note: All variables appear in natural log. form in the regression equation. 
Similarly, the new product development variable (NPD) measure the tendency of allocating resources for the development of new products. The activity is of critical importance for ascertaining a firm's scope of expanding into the production of newly invented products. One advantage of this channel for technological innovation is that it is straight forward and simply aims at new product development. The NPD variable is measured by the value of expenditures on the development of new products in an industry.

In addition, foreign technology spillovers are considered as significant source of technology upgrading in latecomers (Lall, 2003). In this regard, FDI and certain activities of MNEs are of critical importance. FDI my cause the transfer of technology to domestic market as the domestic enterprises interact with foreign enterprises. FDI affect the level of innovation capability in the host country through R\&D related activities of MNEs and their sharing of managerial skills, knowledge spillovers, movement of trained labour and demonstration effect. It also provides spillovers by increasing competition in the domestic market, by coordinating with local firms through forward and backwards linkages within supply chain etc. We proxied the For-tech variable by measuring the value of fixed assets of foreign enterprises in an industry. We prefer using values of For-tech over intensity measures (FDI divided by gross output value or revenue of an industry) to refer whether any significant effect is caused by foreign phenomenon rather than change in the denominator (Hagedoorn \& Wang, 2012; Rothaermel \& Hess, 2004).

The Skill_int. variable measures the technological expertise of personnel engaged in innovation activities. Skill and capacity of an economy is crucial to reap the advantage of domestic and foreign knowledge creating resources ( $\mathrm{Zhu} \& \mathrm{Fu}, 2013)$. In addition, it is the ability to internalise the external technology and modify it to fit industry specific features (Narula, 2002). Skill intensity performs two related functions: First, it represents the skill and expertise of technical personnel to imitate, assimilate and learn from foreign technology; second, it defines the absolute technological level of an industry and the technological gap between two representative industries. In other words, it determines the rate of foreign technology transfer. The Skill int. variable is proxied by the share of scientific and technological development staff to overall employees in an industry.

\subsection{Control variables}

For robustness, we have also included several control variables into our empirical framework as represented by the variables on China's inclusion in WTO (WTO), factor endowment (K/L) and institutions (I). China's inclusion in WTO is another milestone in trade history as it changed the structure of China's integration into world trade and has pushed the capability of domestic firms (Brandt \& Thun, 2010). The integration is expected to have positive impact on China's export sophistication. We introduce a dummy variable 'WTO' to capture this effect. It takes value of 1 for the years 2001-2004. Although the year of inclusion is 2002, we also give same weight to the preparatory year i.e., 2001 and the following two years i.e., 2003, 2004.

Table 2. Summary statistics of variables

\begin{tabular}{llllll}
\hline Variables & Obs. & Mean & St. Dev & Min & Max \\
\hline $\begin{array}{l}\text { Dependent Variable } \\
\text { EXP }\end{array}$ & 256 & 9.4307 & 1.0810 & 6.4547 & 12.4206 \\
$\begin{array}{l}\text { Independent Variables } \\
\text { K/L }\end{array}$ & 256 & 8.4287 & 1.4922 & 4.6935 & 10.5074 \\
R\&D_Int. & 256 & 5.8394 & 1.3779 & 2.3084 & 7.7478 \\
Patent_emp & 256 & -6.4718 & 1.2787 & -11.5870 & -4.1416 \\
Invention_int & 256 & -7.7042 & 1.3618 & -12.2801 & -5.0649 \\
NPD & 240 & -4.7228 & 0.7374 & -7.4631 & -3.5278 \\
For-tech & 256 & 23.7975 & 1.1739 & 21.4293 & 26.6012 \\
WTO & 256 & 0.2500 & 0.4339 & 0 & 1 \\
Skill_Int. & 256 & -3.4678 & 0.6818 & -5.6836 & -0.6123 \\
I & 256 & 7.6868 & 1.3466 & 4.2341 & 10.1805 \\
\hline Allvariabs
\end{tabular}

All variables are in natural log form. Variables names are written as they appear in the main regression equation. Institutional quality (I) is critical to determine the interaction between indigenous and foreign innovation efforts and prevalence of a specific export regime. State institutions play a significant role in this respect by providing preferential treatments to specific industrial exporting activities. The economic rise of Asian countries is associated with the policy perspective on the part of state institutions (Pack \& Westphal, 1986). Strong institutional expertise brings confidence in the private sector and eliminates uncertainty. Strong laws on intellectual property rights avoid misuse of intellectuals' property which leads to encouraging innovation and varieties of new products that, in turn, contribute to export upgrading. The Institutional (I) variable is proxied by the number of private enterprises in an industry. Other variable is physical capital stock to labour ratio (K/L). Physical capital stock is proxied by the value of investment in fixed assets in an industry. All variables appear in the natural log in regression models.

All variables are presented in real US dollars with 2000 as the base year. Table 1 provides description of all variables presented in this paper. Further, we include year dummies to control for time-specific effects and 
contemporaneous correlation (Roodman, 2006). Our sub-sector level sample includes both industry and commodity-group specific source of heterogeneity. We rely on fixed-effect model to control for possible unobservable characteristics of our dataset. This decision is based on the Hausman test statistics which fails to accept the null hypothesis of a Random-effect (RE) estimation. In addition, we control for price fluctuation trends in the international commodity market by including time trend, named as 'TREND', in the final equation. Robust standard errors are calculated in order to obtain heteroskedasticity-controlled concise estimates.

A main concern of researchers while analysing the relationship among trade and different kinds of knowledge creating resources including innovation is the prevalence of endogeneity between the dependent variable and some of the independent variables. Ample studies examine significant endogeneity bias in the relationship among Fortech and export. We deal with this endogeneity problem by applying instrumental variable (IV) method using twoyears lag value of For-tech as instrument. Another issue to be addressed is the possibility of high correlation between For-tech, R\&D_Int, Patent_emp, and I on one hand and Patent_emp and Invention_int on the other hand, which may lead to multicollinearity problem. We also deal with this problem and ran various separate regressions by excluding and including these variables from regression equation. Table 2 provide summary statistics of the variables used.

\section{Results and Discussions}

We begin with estimating equation (1) using fixed-effect method. Results are summarised in Table 3. Columns 18 include results of Different models as estimated by including and excluding variables to perform numerous sensitivity checks. In general, regression results are plausible and observe good explanatory power. The estimated coefficients of $R \& D$ intensity variable are positive and statistically significant. Results are robust across different models, suggesting that spending on R\&D is a crucial determinant of industrial export performance in China. Our estimates are consistent with the recent studies which find a favourable impact of R\&D activities on export (Zhu and $\mathrm{Fu}$ 2013). The finding conforms ample scope for significant rise in China's R\&D spending to GDP ratio in recent years to achieve a notable self-reliant innovative capability and to become innovation driven country by 2020s.

Table 3. Panel Fixed-effect Regression Estimates

\begin{tabular}{|c|c|c|c|c|c|c|c|c|}
\hline EXP & Model 1 & Model 2 & Model 3 & Model 4 & Model 5 & Model 6 & Model 7 & Model 8 \\
\hline Constant & $\begin{array}{l}-5.191 \\
(5.766)\end{array}$ & $\begin{array}{l}-4.779 \\
(7.158)\end{array}$ & $\begin{array}{l}-3.691 \\
(5.808)\end{array}$ & $\begin{array}{l}-4.691 \\
(5.660)\end{array}$ & $\begin{array}{l}-1.077 \\
(6.149)\end{array}$ & $\begin{array}{l}-1.356 \\
(6.160)\end{array}$ & $\begin{array}{l}9.208 * * * \\
(1.491)\end{array}$ & $\begin{array}{l}-4.980 \\
(5.152)\end{array}$ \\
\hline R\&D_Int. & $\begin{array}{l}0.143 * * * \\
(0.040)\end{array}$ & & $\begin{array}{l}0.136 * * * \\
(0.029)\end{array}$ & $\begin{array}{l}0.147 * * * \\
(0.025)\end{array}$ & & & & \\
\hline Patent_emp & $\begin{array}{l}0.199 * \\
(0.111)\end{array}$ & & & & $\begin{array}{l}0.289 * * \\
(0.099)\end{array}$ & & $\begin{array}{l}0.259 * \\
(0.126)\end{array}$ & \\
\hline Invention_int & & $\begin{array}{l}0.178 * * \\
(0.075)\end{array}$ & $\begin{array}{l}0.072 \\
(0.056)\end{array}$ & & & $\begin{array}{l}0.119^{*} \\
(0.058)\end{array}$ & & \\
\hline Skill_int. & $\begin{array}{l}0.337 * * \\
(0.138)\end{array}$ & & $\begin{array}{l}0.313 * * \\
(0.146)\end{array}$ & $\begin{array}{l}0.326 * * \\
(0.152)\end{array}$ & $\begin{array}{l}0.281 * * \\
(0.118)\end{array}$ & $\begin{array}{l}0.342 * * \\
(0.155)\end{array}$ & $\begin{array}{l}0.173 \\
(0.126)\end{array}$ & $\begin{array}{l}0.299 * \\
(0.160)\end{array}$ \\
\hline FDI & $\begin{array}{l}0.664 * * \\
(0.234)\end{array}$ & $\begin{array}{l}0.599 * \\
(0.320)\end{array}$ & $\begin{array}{l}0.568 * * \\
(0.246)\end{array}$ & $\begin{array}{l}0.583 * * \\
(0.244)\end{array}$ & $\begin{array}{l}0.538 * \\
(0.254)\end{array}$ & $\begin{array}{l}0.512 * \\
(0.265)\end{array}$ & & $\begin{array}{l}0.578 * * \\
(0.228)\end{array}$ \\
\hline NPD. & & & $\begin{array}{l}0.133 \\
(0.094)\end{array}$ & $\begin{array}{l}0.146 \\
(0.094)\end{array}$ & $\begin{array}{l}0.120 \\
(0.103)\end{array}$ & $\begin{array}{l}0.167 \\
(0.105)\end{array}$ & $\begin{array}{l}0.228 * * \\
(0.083)\end{array}$ & $\begin{array}{l}0.263 * * * \\
(0.087)\end{array}$ \\
\hline I & & & & & & & $\begin{array}{l}0.341 * * * \\
(0.096)\end{array}$ & $\begin{array}{l}0.399 * * * \\
(0.084)\end{array}$ \\
\hline WTO & & $\begin{array}{l}0.181 * * \\
(0.075)\end{array}$ & & & & & & \\
\hline $\mathrm{K} / \mathrm{L}$ & $\begin{array}{l}0.217 * * * \\
(0.047)\end{array}$ & $\begin{array}{l}0.275 * * * \\
(0.057)\end{array}$ & $\begin{array}{l}0.279 * * * \\
(0.058)\end{array}$ & $\begin{array}{l}0.283 * * * \\
(0.059)\end{array}$ & $\begin{array}{l}0.300 * * * \\
(0.052)\end{array}$ & $\begin{array}{l}0.315 * * * \\
(0.057)\end{array}$ & $\begin{array}{l}0.219 * * * \\
(0.065)\end{array}$ & $\begin{array}{l}0.127 * * \\
(0.057)\end{array}$ \\
\hline TREND & $\begin{array}{l}0.163 * * * \\
(0.032)\end{array}$ & $\begin{array}{l}0.123 * * \\
(0.051)\end{array}$ & $\begin{array}{l}- \\
0.146^{* * *} \\
(0.035)\end{array}$ & $\begin{array}{l}0.136 * * * \\
(0.033)\end{array}$ & $\begin{array}{l}0.162 * * * \\
(0.030)\end{array}$ & $\begin{array}{l}- \\
0.133 * * * \\
(0.039)\end{array}$ & $\begin{array}{l}- \\
0.105 * * * \\
(0.029)\end{array}$ & $\begin{array}{l}- \\
0.140 * * * \\
(0.032)\end{array}$ \\
\hline Hausman & $\mathrm{FE}$ & $\mathrm{FE}$ & $\mathrm{FE}$ & $\mathrm{FE}$ & $\mathrm{FE}$ & $\mathrm{FE}$ & $\mathrm{FE}$ & $\mathrm{FE}$ \\
\hline R-Squared & 0.755 & 0.668 & 0.718 & 0.715 & 0.720 & 0.693 & 0.715 & 0.735 \\
\hline Observations & 256 & 256 & 240 & 240 & 240 & 240 & 240 & 240 \\
\hline
\end{tabular}

* Significance levels of $10 \%$.

** Significance levels of $15 \%$.

*** Significance levels of $1 \%$.

Note: Robust standard errors are provided in parenthesis. 
The estimates of innovation capability and invention intensity are positive and statistically significant, suggesting that patents are significant driver of the export performance of manufacturing industries. Our results also confirm the emerging importance of recent surge in patent applications by Chinese in home and abroad, in China's export competitiveness. The results are consistent to several changes in model specification. An important point is discerned from Table-3. The impact of innovation capability on export is larger when innovation is proxied by patent applications rather than R\&D intensity, as in all cases of model specifications, coefficient magnitude of patent applications is greater than that of $R \& D$ intensity. The finding suggests that certain arrangements which increase the proportion of the conversion of absolute values of R\&D spending into invention or patenting will intensify the contribution of innovation to export. It implies that increasing the speed of such R\&D activities that lead to multiplying the number of patent applications can speed-up the expansion in technical content of export. The estimated coefficients of new product intensity are also positive and statistically significant, and consistent to different models. The result explains the promising role of spending on the development of new products on export performance. Further, Table 3 shows that the coefficient magnitudes of new product intensity are greater when they appear together with institutional quality variable. It shows that benefit of innovation through spending on new product is larger when institutional effectiveness is pervasive. Similarly, estimates on FDI are positive and significant, indicating a consistent and statistically significant impact of foreign investment on export in China. The evidence is robust across different models. These findings confirm that China's opening-up strategy has been remarkable and still successfully contributing to export upgrading. Our results confirm the findings of Brandt and Thun (2014) and Zhu and Fu (2013).

Table 4. Panel Instrumental Variable (IV) Regression Estimates

\begin{tabular}{|c|c|c|c|c|c|c|c|}
\hline EXP & Model 1 & Model 2 & Model 3 & Model 4 & Model 5 & Model 6 & Model 7 \\
\hline Cons. & $\begin{array}{l}-0.906 \\
(2.699)\end{array}$ & $\begin{array}{l}-2.378 \\
(2.878)\end{array}$ & $\begin{array}{l}-1.450 \\
(2.800)\end{array}$ & $\begin{array}{l}-5.904 * \\
(3.013)\end{array}$ & $\begin{array}{l}-1.977 \\
(3.040)\end{array}$ & $\begin{array}{l}-3.703 \\
(2.838)\end{array}$ & $\begin{array}{l}-5.899 * * \\
(2.940)\end{array}$ \\
\hline R\&D_Int. & $\begin{array}{l}0.269 * * * \\
(0.074)\end{array}$ & $\begin{array}{l}0.310^{* * *} \\
(0.080)\end{array}$ & & & & $\begin{array}{l}0.362 * * * \\
(0.075)\end{array}$ & \\
\hline Patent_emp & $\begin{array}{l}0.260 * * * \\
(0.054)\end{array}$ & & $\begin{array}{l}0.319 * * * \\
(0.051)\end{array}$ & & & & \\
\hline Invention_int & & $\begin{array}{l}0.084 * \\
(0.045)\end{array}$ & & & $\begin{array}{l}0.160 * * * \\
(0.044)\end{array}$ & & \\
\hline Skill_Int. & $\begin{array}{l}0.214 * * * \\
(0.064)\end{array}$ & $\begin{array}{l}0.216 * * * \\
(0.068)\end{array}$ & $\begin{array}{l}0.186^{* * *} \\
(0.067)\end{array}$ & & $\begin{array}{l}0.227 * * * \\
(0.071)\end{array}$ & $\begin{array}{l}0.228 * * * \\
(0.068)\end{array}$ & $\begin{array}{l}0.246 * * * \\
(0.074)\end{array}$ \\
\hline NPD & & $\begin{array}{l}0.240 * * \\
(0.102)\end{array}$ & $\begin{array}{l}0.278 * * * \\
(0.095)\end{array}$ & $\begin{array}{l}0.529 * * * \\
(0.100)\end{array}$ & $\begin{array}{l}0.356^{* * * *} \\
(0.100)\end{array}$ & $\begin{array}{l}0.244 * * \\
(0.103)\end{array}$ & $\begin{array}{l}0.420 * * * \\
(0.102)\end{array}$ \\
\hline FDI & $\begin{array}{l}0.485 * * * \\
(0.128)\end{array}$ & $\begin{array}{l}0.541 * * * \\
(0.140)\end{array}$ & $\begin{array}{l}0.618^{* * *} \\
(0.129)\end{array}$ & $\begin{array}{l}0.648 * * * \\
(0.142)\end{array}$ & $\begin{array}{l}0.614 * * * \\
(0.139)\end{array}$ & $\begin{array}{l}0.561 * * * \\
(0.141)\end{array}$ & $\begin{array}{l}0.688 * * * \\
(0.140)\end{array}$ \\
\hline I & & & & $\begin{array}{l}0.263 * \\
(0.157)\end{array}$ & & & $\begin{array}{l}0.188 \\
(0.155)\end{array}$ \\
\hline $\mathrm{K} / \mathrm{L}$ & $\begin{array}{l}0.063 \\
(0.048)\end{array}$ & $\begin{array}{l}0.065 \\
(0.051)\end{array}$ & $\begin{array}{l}0.095 * \\
(0.050)\end{array}$ & $\begin{array}{l}0.141 * * \\
(0.056)\end{array}$ & $\begin{array}{l}0.120 * * \\
(0.053)\end{array}$ & $\begin{array}{l}0.063 \\
(0.051)\end{array}$ & $\begin{array}{l}0.121 * * \\
(0.055)\end{array}$ \\
\hline Period-effect & Yes & Yes & Yes & Yes & Yes & Yes & Yes \\
\hline R-Squared & 0.794 & 0.778 & 0.785 & 0.725 & 0.756 & 0.773 & 0.739 \\
\hline No. of Obs. & 224 & 224 & 224 & 224 & 224 & 224 & 224 \\
\hline
\end{tabular}

* Significance levels of $10 \%$.

** Significance levels of $15 \%$.

*** Significance levels of $1 \%$.

Note: Standard errors are provided in parenthesis.

Similarly, we find a significant positive impact of skill intensity on export performance of China's manufacturing industries. The result is robust across different models. It corroborates the role of higher education and the rising quality of China's science and technology institutes, as well as the emerging focus on technological research laboratories ${ }^{1}$.

Institutional quality variable shows a statistically significant positive effect on industrial export. The result is consistent to different sensitivity checks by allowing changes in model specifications, suggesting that institutions are critical to determine the sophistication level of export and the terms of a country's exposure to world market.

The WTO variable is statistically significant and shows right sign across different models. It suggests that China's inclusion of WTO has expanded the scope of middle kingdom's trade expertise. Estimated coefficient of

\footnotetext{
1 The prestige of Chinese researchers and academicians are also recognised by world's leading institutions and China is ranked second in the USA among most-cited countries by papers in ESI in 2015 (NBS: 2015)
} 
capital-labour ratio is also significant and positive. The evidence is consistent across different models.

We deal with possible endogeneity bias in the relationship among FDI and export upgrading by applying (IV) method and results are presented in Table 4. The coefficient estimates are broadly consistent with that of fixedeffect method, suggesting robustness of the estimates and showing a little endogeneity bias in our estimates. For instance, R\&D intensity, innovation capability, invention intensity, new product development and skill intensity variables have a statistically significant positive impact on export performance of China's manufacturing industries. The evidence is consistent across different models. Similarly, foreign technology variable has a significant positive impact on export performance, suggesting that foreign technology transfer is a critical driver of export. Similarly, institutional quality and capital labour ratio demonstrate the expected positive sign which is significant and consistent across different models.

Our results so far have argued that R\&D intensity, innovation capability, invention intensity, skill intensity, foreign technology, new product development and institutions are main drivers that determine the competitiveness of an industry's export structure in emerging countries. It proposes that China should continue stimulating efforts to promote domestically-driven innovative activities to develop a sound and determined national innovation system, as well as, being a latecomer, it should keep on striving to create broad-based spillovers from foreign technology. Further, findings of the paper extend the results of $\mathrm{Fu}$ and Gong (2011) to innovation-exporting relationship indicating that a mix of both self-reliant and foreign innovation efforts are crucial for developing a competitive export structure.

\section{Conclusion}

The relationship between technological innovation and export is important as it has been viewed as engine of longrun economic growth. In fact, evidence of some developing countries has concluded that expanding into new products and enhancing the technical content of export bundles instils true benefits from trade. However, an empirical investigation of the drivers of this technological process have not yet attracted much attention. The paper aims to fill the gap in existing literature by exploring the role of different kinds of innovation as potential determinants of an astounding export performance in some of the developing countries. In this regard, we rely on using a unique sub-sector level dataset on China's manufacturing industries and comprehensively investigate the integrated impact of the different kinds of technological innovation including R\&D intensity, innovation capability, invention intensity, skill intensity, foreign technology, new product development and the institutional quality on China's industrial export performance over 1998-2013 period. The results are summarised:

First, R\&D intensity, innovation capability, invention intensity and the activities related to new product development, positively influence export performance of China's manufacturing industries. This finding validates the scope of ongoing technology upgrading efforts which are specifically aimed at enhancing domestic innovative capability to transform trade pattern into a sophisticated structure of exports. Similarly, foreign technology transfer as proxied by FDI, examine a positive and significant impact on export implying that research and development activities of MNEs and the acquisition of foreign technology are still a major determinant of export in China. A notable aspect of this result reveal that a mix of domestic and foreign innovation efforts is of crucial importance for China's plan to achieve a threshold level of capability and shifting the focus to manufacturing industries.

Further, skill intensity has a significant positive impact on export, suggesting that China has maintained a specific level of skilled resource, such as technicians and other technology development personnel, to reap the advantage of both indigenous and foreign innovation channels. Furthermore, the effect of institutional quality is positive and significant as expected which proves the active role of government in China's remarkable export performance in decades and its contribution to technological upgrading efforts in the pursuit of export upgrading through transforming the industrial structure to CTIs. Moreover, our results of WTO variable demonstrate that inclusion of China into WTO has benefited the country in its bid of trade expansion.

\section{References}

Aghion, P., Howitt, P., Brant-Collett, M., \& García-Peñalosa, C. (1998). Endogenous growth theory. MIT press.

Akamatsu, K. (1961). A theory of unbalanced growth in the world economy. Weltwirtschaftliches Archiv, 86, 196217.

Amighini, A., \& Sanfilippo, M. (2014). Impact of South-South FDI and trade on the export upgrading of African economies. World Development, 64, 1-17.

Amiti, M., \& Freund, C. (2010). The anatomy of China's export growth. In R. Feenstra, \& S. J. Wei (Eds.), China's growing role in world trade (pp. 35-56). University of Chicago Press.

Amsden, A. H. (1986). The direction of trade — past and present — and the 'learning effects' of exports to different directions. Journal of Development Economics, 23(2), 249-274.

Amsden, A. H. (1989). Asia's next giant: South Korea and late industrialization. New York and Oxford: Oxford University Press on Demand.

Assche, A. V., \& Gangnes, B. (2010). Electronics production upgrading: Is China exceptional?. Applied 
Economics Letters, 17(5), 477-482.

Bas, M., \& Strauss-Kahn, V. (2015). Input-trade liberalization, export prices and quality upgrading. Journal of International Economics, 95(2), 250-262.

Brooks, E. L. (2006). Why don't firms export more? Product quality and Colombian plants. Journal of development Economics, 80(1), 160-178.

Crespo, N., \& Fontoura, M. P. (2007). Determinant factors of FDI spillovers-what do we really know?. World Development, 35(3), 410-425.

Czarnitzki, D., Kraft, K., \& Thorwarth, S. (2009). The knowledge production of 'R'and 'D'. Economics Letters, 105(1), 141-143.

Dai, M., Maitra, M., \& Yu, M. (2016). Unexceptional exporter performance in China? The role of processing trade. Journal of Development Economics, 121, 177-189.

Davis, D. R. (1995). Intra-industry trade: a Heckscher-Ohlin-Ricardo approach. Journal of international Economics, 39(3), 201-226.

Fagerberg, J. (1988). Why growth rates differ. In G. Dosi, C. Freeman, R. Nelson, G. Silverberg, \& L. Soete (Eds.), Technical change and economic theory (pp. 432-457). London: Pinter Publishers.

$\mathrm{Fu}, \mathrm{X}$. , \& Gong, Y. (2011). Indigenous and foreign innovation efforts and drivers of technological upgrading: evidence from China. World development, 39(7), 1213-1225.

$\mathrm{Fu}$, X., Pietrobelli, C., \& Soete, L. (2011). The role of foreign technology and indigenous innovation in the emerging economies: technological change and catching-up. World Development, 39(7), 1204-1212.

Girma, S. (2005). Absorptive capacity and productivity spillovers from FDI: a threshold regression analysis. Oxford Bulletin of Economics and Statistics, 67(3), 281-306.

Greenhalgh, C. (1990). Innovation and trade performance in the United Kingdom. the economic Journal, 100(400), 105-118.

Greenhalgh, C., Taylor, P., \& Wilson, R. (1994). Innovation and export volumes and prices-a disaggregated study. Oxford Economic Papers, 46, 102-135.

Grossman, G. M., \& Helprnan, E. (1994). Endogenous innovation in the theory of growth. The journal of economic perspectives, 8(1), 23-44.

Grossman, G. M., \& Helpman, E. (1995). Technology and trade. In: Grossman, G.M., Rogoff, K. (Eds.), Handbook of international economics, 3, 1279-1337.

Gurmu, S., \& Pérez-Sebastián, F. (2008). Patents, R\&D and lag effects: evidence from flexible methods for count panel data on manufacturing firms. Empirical Economics, 35(3), 507-526.

Hagedoorn, J., \& Wang, N. (2012). Is there complementarity or substitutability between internal and external R\&D strategies?. Research Policy, 41(6), 1072-1083.

Harding, T., \& Javorcik, B. S. (2012). Foreign direct investment and export upgrading. Review of Economics and Statistics, 94(4), 964-980.

Harris, R., \& Moffat, J. (2011). R\&D, innovation and exporting. SERC Discussion Paper 73. Spatial Economics Research Centre, London.

Harris, R., \& Trainor, M. (1995). Innovations and R \& D in Northern Ireland manufacturing: a Schumpeterian approach. Regional studies, 29(7), 593-604.

Hausmann, R., Hwang, J., \& Rodrik, D. (2007). What you export matters. Journal of economic growth, 12(1), 125.

Hausmann, R., \& Rodrik, D. (2003). Economic development as self-discovery. Journal of development Economics, 72(2), 603-633.

Hidalgo, C. A., \& Hausmann, R. (2009). The building blocks of economic complexity. proceedings of the national academy of sciences, 106(26), 10570-10575.

Hidalgo, C. A., Klinger, B., Barabási, A. L., \& Hausmann, R. (2007). The product space conditions the development of nations. Science, 317(5837), 482-487.

Hummels, D., \& Klenow, P. J. (2005). The variety and quality of a nation's exports. The American Economic Review, 95(3), 704-723.

Jarreau, J., \& Poncet, S. (2012). Export sophistication and economic growth: Evidence from China. Journal of development Economics, 97(2), 281-292.

Jefferson, G., Albert, G. Z., Xiaojing, G., \& Xiaoyun, Y. (2003). Ownership, performance, and innovation in China's large-and medium-size industrial enterprise sector. China economic review, 14(1), 89-113.

Johnson, C. (1982). MITI and the Japanese miracle: the growth of industrial policy: 1925-1975. Stanford: Stanford University Press.

Khandelwal, A. (2010). The long and short (of) quality ladders. The Review of Economic Studies, 77(4), 14501476.

Kohli, A. (2004). State-directed development: political power and industrialization in the global periphery. New York: Cambridge University Press. 
Koopman, R., Wang, Z., \& Wei, S. J. (2012). Estimating domestic content in exports when processing trade is pervasive. Journal of development economics, 99(1), 178-189.

Lall, S. (2003). Foreign direct investment, technology development and competitiveness: Issues and evidence. In S. Lall, \& S. Urata (Eds.), Competitiveness, FDI and Technological Activity in East Asia, Cheltanham, UK: Association with the World Bank, Edward Elgar.

Lall, S., Weiss, J., \& Zhang, J. (2006). The "sophistication" of exports: a new trade measure. World development, 34(2), 222-237.

Lardy, N. R. (1992). Chinese foreign trade. The China Quarterly, 131, 691-720.

Lemoine, F., \& Ünal-Kesenci, D. (2004). Assembly trade and technology transfer: the case of China. World development, 32(5), 829-850.

Lin, J. Y. (2012). New structural economics: a framework for rethinking development. Washington, DC. The World Bank.

Lipsey, R. E., \& Sjöholm, F. (2011). South-south FDI and development in East Asia. Asian Development Review, 16(3), 447-464.

Liu, X., \& Buck, T. (2007). Innovation performance and channels for international technology spillovers: Evidence from Chinese high-tech industries. Research policy, 36(3), 355-366.

Lo, D., \& Chan, T. M. (1998). Machinery and China's nexus of foreign trade and economic growth. Journal of International Development, 10(6), 733-749.

Ma, H., Wang, Z., \& Zhu, K. (2015). Domestic content in China's exports and its distribution by firm ownership. Journal of Comparative Economics, 43(1), 3-18.

Mairesse, J., \& Mohnen, P. (2002). Accounting for innovation and measuring innovativeness: an illustrative framework and an application. The American Economic Review, 92(2), 226-230.

Minondo, A. (2010). Exports' quality-adjusted productivity and economic growth. The Journal of International Trade \& Economic Development, 19(2), 257-287.

Narula, R. (2002). The implications of growing cross-border interdependence for systems of innovation. MERIT, Infonomics Research Memorandum Series No. 16.

OECD (2014). Science and Technology Industry Outlook. Paris: OECD.

Pack, H., \& Westphal, L. E. (1986). Industrial strategy and technological change: theory versus reality. Journal of Development Economics, 22(1), 87-128.

Poncet, S., \& de Waldemar, F. S. (2013). Export upgrading and growth: the prerequisite of domestic embeddedness. World Development, 51, 104-118.

Posner, M. V. (1961). International trade and technical change. Oxford economic papers, 13(3), 323-341.

Rodil, Ó., Vence, X., \& del Carmen Sánchez, M. (2015). The relationship between innovation and export behaviour: The case of Galician firms. Technological Forecasting and Social Change, 113B, 248-265.

Rodrik, D. (2006). What's so special about China's exports?. China \& World Economy, 14(5), 1-19.

Romer, P. M. (1990). Endogenous technological change. Journal of political Economy, 98(5, Part 2), S71-S102.

Romer, P. M. (1994). The origins of endogenous growth. The journal of economic perspectives, 8(1), 3-22.

Roodman, D. (2006). How to do xtabond2: An introduction to "difference" and "system" GMM in Stata. CGD Working Paper No. 103. Washington, DC: Center for Global Development.

Rothaermel, F. T., \& Hess, A. M. (2007). Building dynamic capabilities: Innovation driven by individual-, firm-, and network-level effects. Organization science, 18(6), 898-921.

Sheng, B. (2002). Zhongguo Dui Wai Maoyi Zhengce de Zhengzhi Jingji Fenxi (Political Economy of China's Foreign Trade Policy). Shanghai: Shanghai People's Publishing House.

Sheridan, B. J. (2014). Manufacturing exports and growth: When is a developing country ready to transition from primary exports to manufacturing exports?. Journal of Macroeconomics, 42, 1-13.

Sun, Y., \& Du, D. (2010). Determinants of industrial innovation in China: Evidence from its recent economic census. Technovation, 30(9), 540-550.

Schott, P. K. (2008). The relative sophistication of Chinese exports. Economic policy, 23(53), 6-49.

Tang, Y., \& Zhang, K. H. (2016). Absorptive capacity and benefits from FDI: Evidence from Chinese manufactured exports. International Review of Economics \& Finance, 42, 423-429.

Vernon, R. (1966). International investment and international trade in the product cycle. The quarterly journal of economics, 80, 190-207.

Wang, Z., \& Wei, S. J. (2010). What accounts for the rising sophistication of China's exports?. In China's growing role in world trade (pp. 63-104). University of Chicago Press.

Yang, C. H., \& Chen, Y. H. (2012). R\&D, productivity, and exports: Plant-level evidence from Indonesia. Economic Modelling, 29(2), 208-216.

Young, A. (1991). Learning by doing and the dynamic effects of international trade. The Quarterly Journal of Economics, 106(2), 369-405.

Zhu, S., \& Fu, X. (2013). Drivers of export upgrading. World Development, 51, 221-233. 